\title{
La indumentaria como símbolo regional. La tradición inventada en el caso del traje femenino de Montehermoso
}

1. SOBRE LA INDUMENTARIA TRADICIONAL

En general, los museos y las colecciones de indumentaria tradicional suelen presentar sus piezas o sus trajes situándolos históricamente en lo que se considera la sociedad tradicional, pero es muy corriente que no se tengan en cuenta otros factores que también son importantes, como la diversidad espacial y la variabilidad en el tiempo. Esto, lógicamente, no es algo que solamente concierna a la indumentaria, sino que es observable en todos los demás aspectos materiales e inmateriales de la cultura, que muy a menudo tienden a ser presentados en los museos, y en no pocos estudios, como un cliché inmovilizado en el tiempo, estático.

Numerosos trabajos etnográficos pretenden presentarnos cómo era la vida tradicional en tal o cual comunidad, informarnos sobre la arquitectura, la tecnología o la indumentaria tradicionales, o insistir sobre el efecto que el cambio social experimentado en los últimos cincuenta años ha tenido sobre la sociedad tradicional. Una problemática parecida se plantea en torno al concepto de lo popular, y así encontramos trabajos que tratan de diferenciar, por ejemplo, las artes populares o la música popular de aquellas manifestaciones del mismo género que se consideran cultas. La idea de lo popular es, en todo caso, más difícil de aprehender, en tanto que la diferenciación entre lo culto y lo popular puede ser poco clara en muchos casos, y la frontera entre ambos conceptos es, de hecho, sobrepasada continuamente en uno y otro sentido, de modo que lo popular se impregna de lo culto y viceversa. Sea como fuere, el concepto antropológico de la cultura comprende todas estas expresiones intelectuales y materiales, sean populares o cultas, por lo que, en este sentido, la delimitación de uno y otro concepto tiene una importancia secundaria.

Por lo que respecta al término tradicional que utilizan los estudiosos, al menos en España parece referirse a un período de tiempo más o menos prolongado que en cualquier caso comenzaría a tocar a su fin tras la guerra civil de 1936-39 pero que, muy especialmente, se descompone de manera definitiva a partir de la década de los cincuenta. En estos años se operan 
importantes cambios tecnológicos y sociales en el mundo rural, que son fiel reflejo de una creciente hegemonía de la ciudad sobre el campo.

Desde esos años, las comunidades rurales españolas han ido perdiendo la mayor parte de su autarquía y su capacidad de autorregulación económica, cayendo en una relación de creciente dependencia respecto de la ciudad; todo ello ha provocado el abandono de determinadas actividades económicas y sociales y la adopción de otras nuevas procedentes o asimilables al ámbito urbano, lo que ha llevado a distintos investigadores a hablar del fin de la sociedad tradicional. El principal problema no reside tanto en delimitar cuál es el período de tiempo en el que consideramos que se ha desarrollado la sociedad tradicional, como en asumir el hecho de que la cultura se caracteriza, como toda realización humana, por su dinamismo. Puesto que las culturas cambian, se modifican, incorporan nuevos aspectos y abandonan otros, por ello no podemos pensar en modo alguno que la sociedad tradicional, al igual que sus manifestaciones culturales, haya sido un todo estático, sincrónico y aislado ${ }^{1}$, sino que por el contrario, esta sociedad, en España como en otros lugares, ha estado sujeta a la evolución y cambios que afectan a cualquier grupo humano.

Está, por lo tanto, bastante claro que el concepto de lo tradicional no encierra una significación unívoca en cuanto al tiempo; la sociedad tradicional que está parcialmente retratada, por ejemplo, en el Viage de España de Ponz no es la misma que recoge cien años después La Ilustración Española y Americana. Es evidente que a lo largo de todo ese tiempo se producen cambios en la sociedad española que forzosamente influyen en los modos de vida que se suelen considerar única, y un poco alegremente, tradicionales. Tal como han mostrado numerosos trabajos, el estudio de cualquier sociedad tradicional, desde una óptica diacrónica, revela por fuerza una variabilidad a lo largo del tiempo que en ocasiones puede aportar una información que venga a matizar o incluso contradecir ciertas figuras aceptadas o tópicas acerca de esa sociedad 2 .

1 A. ARnholn, "Lo tradicional no es "de siempre", L. Díaz Viana (ed.), Etnología y folklore en Castilla y León (Salamanca: Junta de Comunidades de Castilla y León, 1980), $49-55$.

- Veamos el ejemplo del Valle del Jerte, donde a primera vista podría pensarse que el monocultivo del cerezo ha sido el modus vivendi tradicional. Sin embargo, sabemos que el actual panorama no es más que el resultado de todo un proceso histórico que incluye grandes modificaciones, así, este cultivo principal fue imponiéndose desde la segunda mitad del siglo xviI para enfrentar la crisis económica a que condujo la ruina del otrora próspero castañar. Estos cambios fueron quedando reflejados en todos los aspectos de la vida social y material de la sociedad tradicional: F. FloRes del MANZANO, La tida tradicional en el Valle del Jerte (Mérida: Asamblea de Extremadura, 1992), 29-32. 
Estas reflexiones nos llevan a replantearnos lo que podemos considerar como tradicional en nuestro estudio de la cultura; de hecho, sabemos que cualquier manifestación de la misma aparece en un momento determinado, cambia a lo largo del tiempo y puede desaparecer una vez que su función adaptativa pierde vigencia. Por ello, la indumentaria que habitualmente se considera tradicional ha estado - y a veces todavía está- igualmente sujeta a la variabilidad temporal, de manera que el traje típico de una localidad, comarca o región, pese a ser una forma fosilizada de indumentaria, no deja de tener un origen y una evolución formal que en la mayor parte de los casos no es recogida debidamente, bien por desconocimiento del desarrollo experimentado o bien porque un determinado tipo es el único aceptado como verdadera representación del traje tradicional. Esto es lo que sucede en la mayoría de las colecciones de indumentaria en lo que se refiere a la variabilidad temporal del modelo.

Por otro lado, junto a las tipologías indumentarias que representan a una determinada población, como sucede en Extremadura con los trajes de Garrovillas, Orellana, y otros, existen ciertos modelos que son comúnmente aceptados como el traje de... tal o cual región; así, encontramos el arquetipo del traje de la pubilla catalana, el de la fallera valenciana o el mismo de Montehermoso, que aunque pueden tener su origen en un punto localizado y concreto, tienden a ser interpretados como la representación válida del traje de Cataluña, de Valencia o de Extremadura. Ya hemos abordado antes este tema ${ }^{3}$ y por ello no vamos a insistir, solamente conviene ahora recordar el importante papel que han desempeñado algunas personas desde el mundo de lo culto y determinadas instituciones como la Sección Femenina en este proceso de consolidación de los modelos de trajes regionales (o mejor provinciales), que todavía hoy consideramos como algo inamovible y que nos permiten identificar gráficamente el modo tradicional de vestir en esta o aquella región. En cuanto a la indumentaria, lo mismo que en lo referente a música y bailes tradicionales, la Sección Femenina se guió por su propio y particular concepto de la necesidad de "desentrañar, salvar, revitalizar lo auténticamente Español para edificar sobre ello el futuro de la Patrian; claro que todo ello perseguía una finalidad bien concreta de ofrecer la imagen de una España unida y tradicionalista, ya que estos aspectos folklóricos de la cultura "valen también para realizarse (sic) una estupenda labor política" 4 .

3 J. M. VALADÉS SIERRA, :Indumentaria tradicional en los museos: ¿Cultura popular o arqueología?,, Conferencia Internacional de Colecciones y Museos de Indumentaria (Madrid: Museo Nacional del Pueblo Español, 1993), 219-224.

4 M. J. Sampelayo, "Labor de la Sección Femenina en el resurgimiento del folklore español., Etnología y Tradiciones Populares, I (Zaragoza, 1969), 99-101. 
Si aceptamos que algunos tipos del traje tradicional de determinados puntos han sobrepasado las fronteras locales para convertirse en trajes supracomunales que pueden identificar a toda una provincia o incluso región, tendremos que asumir al menos la posibilidad de que esa evolución formal de la indumentaria de que hablábamos más arriba haya podido seguir líneas distintas o incluso divergentes dependiendo del lugar en que se haya desarrollado. Por tanto, no sólo cuenta aquí de qué modo ha podido cambiar el traje de Don Benito en Don Benito, sino también qué modificaciones ha ido incorporando desde que pasó a ser el traje de Badajoz por obra y gracia de la Sección Femenina ${ }^{5}$. Esto supone que los trajes, después de medio siglo de evolución, pueden en estos momentos ser diferentes en los distintos puntos en que se confeccionan y se usan, y sin embargo, todos ellos son aceptados por la comunidad que los utiliza como el verdadero $y$ tradicional traje heredado de los antepasados. De este modo, la comunidad en que el tipo indumentario tiene su origen se alza en defensora del modelo puro del traje, frente a los modelos falsos o adulterados que confeccionan y utilizan las otras comunidades que se apropian de él.

\section{LA INDUMENTARIA COMO SÍMBOLO GRUPAL}

Algunos autores han señalado ya el papel que, al igual que otras manifestaciones culturales como son la lengua, la religión, el ritual, etc., desempeña la indumentaria en el terreno de la etnicidad. Cuando una comunidad está articulada y se percibe a sí misma como grupo, es corriente que potencie aquellas facetas de la cultura que más puedan aportar a la formación de una imagen grupal, y entre éstas se halla la indumentaria; éste sería en último término el caso de los trajes nacionales o regionales ${ }^{6}$. En general, la importancia que adquiere la manera de vestir como elemento de identificación étnica crece en la medida que el grupo percibe la presencia de otra comunidad dotada de una cultura diferente y, a la vez, tendente a la hegemonía; es, sobre todo, cuando la cultura propia está sujeta a la influencia o incluso a la amenaza por parte de otro grupo, el momento en que la manera de vestir puede convertirse en un símbolo.

s V. Gutierrez Macias, "El traje popular de Extremadura", Etnología y Tradiciones Populares, III (Zaragoza, 1977), 365-405.

- M. A. MORCillo PARÉs, *Aproximación al estudio antropológico de la indumentaria", Conferencia Internacional de Colecciones y Museos de Indumentaria (Madrid: Museo Nacional del Pueblo Español, 1993), 184-187. 
En Gran Bretaña, por ejemplo, la permanencia y popularidad de los trajes nacionales galés y escocés se ha interpretado como una voluntad de estas comunidades por preservar su propia cultura, básicamente representada en las entidades rurales y aisladas, frente a la creciente influencia de la vida urbana, que no dejaba lugar a las manifestaciones vernáculas. No cabe duda de que el uso de la indumentaria se convierte en un acto de afirmación de la etnicidad, y la propia vestimenta termina por ser un símbolo de la nación; esto se percibe muy claramente en el caso escocés, cuyo traje contó con la defensa de numerosos escritores y, especialmente, de Sir Walter Scott, que impulsó la popularidad de esta indumentaria sobre todo desde que la llevó con ocasión de la visita del rey Jorge IV a Edimburgo en 1822. En el caso inglés no se puede rastrear la existencia de un traje popular definitorio porque, a diferencia de Escocia o Gales, Inglaterra no ha sufrido una crisis de identidad, no ha tenido que proteger sus formas culturales frente a una sociedad amenazante ni por lo tanto ha necesitado reafirmarse ${ }^{7}$.

Lógicamente, la utilización de la indumentaria como símbolo de un grupo no es algo exclusivo. Otros aspectos de la cultura son también susceptibles de desempeñar esta función; de hecho, lo habitual es que la etnicidad se refuerce mediante el uso simultáneo de varios elementos simbólicos: las fiestas andaluzas del Rocío que se celebran en Cataluña, por ejemplo, incluyen la presencia y el manejo por parte de la comunidad de una serie de símbolos que tratan de subrayar las diferencias entre la cultura andaluza y la catalana; es así como entran en juego la indumentaria (trajes de faralaes), la simbología religiosa (Virgen del Rocío), la música y la danza (sevillanas, sobre todo, pero también cante flamenco), la lengua (castellano versus catalán), la gastronomía (jamón serrano, pescaíto, manzanilla) e incluso otros aspectos tecnológicos y sociales, como son el desplazamiento a caballo frente al automóvil, la particular concepción del espacio festivo (las casetas), etc. A pesar de que la utilización de los símbolos se hace en un contexto más amplio, entrando en funcionamiento todo un lenguaje simbólico, lo que nos interesa ahora es resaltar los procesos que llevan a que una determinada manifestación cultural se convierta en un emblema del grupo.

La arquitectura, por ejemplo, suele adoptar un carácter simbólico, identificando la casa a la persona o grupo de parentesco que la habita, y reflejando estos individuos su propio sistema de valores en la edificación. Es sabido que la casa desempeña el papel de identificación de la familia

7 N. TARRANT, - Why don't the English have a folk dress?", Etnografika, 4-5 (Nauplio, 1983-85), 7-10. 
en amplias zonas del norte de nuestra Península, donde las personas son conocidas no por su nombre o apellido, sino por la denominación de la casa, casona, caserío, casoa, masía, etc. Pero además, los tipos arquitectónicos también son susceptibles de convertirse en símbolos que identifican a toda una comunidad, más o menos amplia, haciendo que se reproduzcan las formas constructivas o que incluso puedan llegar a fosilizarse, negándose a una evolución que podría terminar con la destrucción del símbolo. Si se nos pide que escojamos un símbolo de Asturias, por ejemplo, es muy fácil que pensemos de inmediato en el tipo más conocido de hórreo asturiano, de madera, planta cuadrangular y tejado a cuatro aguas; en este caso, un modelo arquitectónico popular se ha convertido en un símbolo, de tal modo que, incluso cuando ha perdido su funcionalidad, se intenta preservar de una manera explícita, tal como lo prueba la disposición legal que declara Bien de Interés Cultural a todas las edificaciones de este tipo con más de cien años de antigüedad.

La lengua es, sin duda, un aspecto básico de la cultura, y por ello es otro de esos instrumentos que pueden adquirir la condición de símbolo de un grupo frente a otro. La insistencia en utilizar el idioma propio revela una actitud de afirmación étnica en situaciones de contacto intercultural; los emigrados, por ejemplo, suelen utilizar la lengua materna en su hogar, como una parte de la transmisión de su propia cultura a los hijos. Al mismo tiempo, la actitud contraria, la de intentar aprender la lengua de la sociedad de acogida, se interpreta como una manifestación de interés por la otra cultura y un canal apto para favorecer el contacto interétnico; en definitiva, el abandono de la lengua propia y el aprendizaje de la ajena aparece como el paso más importante y previo para el cambio en la identificación étnica del individuo ${ }^{8}$. En otros contextos, las sociedades pueden hacer del uso y difusión de su lengua la principal batalla para su identificación como pueblos, y ahí tenemos el problema de la normalización lingüistica de Cataluña; en Extremadura, por otra parte, se ha señalado ya hace tiempo que ael pueblo extremeño por una de las pocas cosas que se siente identificado es por sus diferencias lingüísticas respecto a la comunidad castellana" ${ }^{9}$, afirmación que parece otorgar también a las formas dialectales la capacidad de representar a todo un pueblo.

Los rituales festivos son también un canal idóneo para la expresión de la etnicidad de un grupo, y es frecuente que los iconos, las imágenes

8 H. ESSER, "Length of Stay and assimilation of migrant workers: an empirical study., Migrant workers in metropolitan cities, Contributions to the First Workshop in
Birmingham (Estrasburgo, 1980), 27-53.

9 F. FloRes Del MANZANO, El problema de la identidad de Extremadura", Alcāntara, 13-14 (1988), 33-43. 
religiosas, se conviertan en el referente en torno al cual se aúna la comunidad. Isidoro Moreno ha mostrado los distintos niveles de integración socio-cultural en torno a una imagen o ritual ${ }^{10}$, desde el nivel grupal al semicomunal, comunal y supracomunitario. En todos estos casos la imagen religiosa es el símbolo que identifica al grupo y le permite autopercibirse como tal; si tratamos de pensar, por ejemplo, en un símbolo netamente aragonés, es muy posible que nos acordemos de la Virgen del Pilar. En otras ocasiones esta identificación puede tener el significado de afirmación étnica frente a otro grupo con el que se convive, no necesariamente en términos de hostilidad ni tan siquiera de desequilibrio, y entonces el grupo escoge la imagen religiosa como símbolo y reflejo de sus propias características ${ }^{11}$. Pero no sólo la imagen, sino también los rituales - religiosos o civiles- pueden llegar a adquirir esa significación emblemática, tal como sucede con los Sanfermines pamploneses, que identifican a Navarra, o las Fallas de Valencia, que representan a toda la Comunidad. Evidentemente, los ejemplos que citamos no implican que esos elementos, materiales o no, sean capaces de representar a todo un pueblo: Navarra es más que sus Sanfermines, y Asturias más que sus hórreos, pero no deja de ser cierto que los aspectos escogidos desempeñan una función de símbolo de una determinada comunidad, no sólo para quienes no pertenecen a ella y los ven desde fuera, sino también en muchos casos para los propios miembros de ese grupo humano.

Pero, volviendo a la indumentaria, hemos visto ya un ejemplo, el de Escocia, en que un determinado modelo de traje asume el carácter de símbolo supracomunitario; no se trata ya del traje que identifica a un pueblo o comarca, sino que es todo un país el que está representado por él. En España quizá no tengamos un caso tan claro de indumentaria como símbolo de toda una sociedad; de entrada, no podemos hablar de la existencia de un traje nacional español - como tampoco de una arquitectura popular española, de una artesanía española, etc.-, pero sí es posible encontrar ciertos tipos de vestiduras que han sido o son tradicionalmente identificativas de alguna comunidad más o menos amplia. En general, tenemos una serie de imágenes relativamente estereotipadas acerca de los trajes regionales o provinciales españoles y, en este sentido, estos modelos indumentales sí cumplen la función de símbolo de las regiones o provincias de donde proceden; sin embargo, si se nos pide que pensemos en

10 I. MORENo, Cofradías andaluzas y fiestas: aspectos antropológicos», H. Velasco (ed.), Tiempo de fiesta (Madrid: Ed. Tres Catorce Diecisiete, 1982), 71-93.

11 J. M. VAladés SierRa, *El ritual como afirmación de la identidad. Un caso práctico en la sociedad industrial., Mediterrâneo, 3 (1993a), 221-231. 
un símbolo de cada una de las regiones españolas, es probable que ninguna de ellas quede representada sobre todo por su traje regional, de modo que en estos casos no se da la fuerza que la indumentaria tiene, por ejemplo, como emblema de Escocia.

En Extremadura encontramos la existencia o la memoria de una considerable cantidad de trajes tradicionales locales, tanto masculinos como femeninos, pero en los últimos setenta $u$ ochenta años parece haberse impuesto el traje femenino de Montehermoso como representación de la tradicional manera de vestir extremeña. Cuando la Hispanic Society of America encargó a Sorolla una serie de cuadros sobre temas costumbristas españoles, el genial pintor se dedicó a recorrer España en busca de modelos, y al llegarle el turno a Extremadura, se instaló en la casa que don Pedro Sánchez-Ocaña Delgado poseía en Plasencia. Sus anfitriones le proporcionaron a Sorolla un grupo de modelos ataviados con el traje típico precisamente de Montehermoso, y entre octubre y noviembre de 1917 fue tomando forma el cuadro titulado "Mercado de cerdos en Plasencia", en el que aparecen cuatro mujeres, cuatro hombres y una niña ataviados con las vestiduras típicas del citado pueblo ${ }^{12}$. Es decir, que al menos desde aquellos años, pero seguramente desde antes, por alguna razón y para algunas personas, el traje de Montehermoso era capaz de resumir la riqueza indumental de la región extremeña; posteriormente este tipo ha estado presente en diversas exposiciones como "el traje de Extremaduran ${ }^{13}$ y ha sido definido como el más representativo de la región "por su belleza y colorido y la gracia de la gorra con el espejo" ${ }^{14}$. En la actualidad, el traje femenino de Montehermoso, o tal vez mejor su peculiar gorra, se ha decantado como el modelo más conocido de la indumentaria tradicional extremeña, y es una obligada referencia icónica de la región; citaremos sólo algunos ejemplos bastante significativos de ello.

- Ha sido popularizado en las típicas munecas que se venden en el comercio ataviadas con los trajes regionales de España.

- Para una muestra de carácter mundial, como fue la Exposición Universal de Sevilla en 1992, la Junta de Extremadura editó un lujoso libro destinado a dar a conocer la región en el resto del mundo, titulado Extremadura. A world in itself; en esa publicación, cada tema aparece acompanado de una sola fotografía, y la escogida para ilustrar el artículo sobre "Folclore" representa a una joven ataviada con la típica gorra montehermoseña.

12 R. M. ANDERSON, Costumes painted by Sorolla in bis provinces of Spain (New York: Hispanic Society of America, 1957), 60-62.

13 J. M. VAladés SIERRA, op. cit. (1993), 222.

it V. GutiérRez Macias, op. cit., 367. 
- Para ilustrar la voz "Folklore" de la conocida Gran Enciclopedia Extremeña, de Ediciones Extremeñas S.A. (1991, V: 9), también se ha elegido la imagen de una joven tocada con la misma gorra.

- Una de las marcas extremeñas de productos alimenticios más conocida es la que se llama, precisamente, "La Gorra", y su logotipo es también la fotografía de una joven que se cubre con la citada prenda.

Podríamos seguir hasta el hartazgo con ejemplos que ilustran este fenómeno; en todo caso, lo que queda claro es que, en cualquier selección de trajes típicos españoles, Extremadura es representada por el traje femenino de Montehermoso. Por ahora no vamos a entrar en más detalles sobre este atuendo, pero sí lo haremos más adelante, pues hay varias matizaciones que conviene hacer.

De acuerdo, se nos dirá, el traje de Montehermoso es el más emblemático de Extremadura, más que el de Don Benito, Castuera, Olivenza o Malpartida de Plasencia, pero ¿eso lo convierte en un símbolo regional? Hemos de responder que sí, y trataremos de razonarlo. Elijamos un criterio para determinar cuáles son los símbolos de Extremadura; el símbolo es una convención consuetudinaria, que cumple la función de que una imagen represente una idea mediante una asociación arbitraria, pero culturalmente aceptada ${ }^{15}$. Esto quiere decir que entre el símbolo -que puede ser material o inmaterial - y la idea que representa, no existe una relación directa, sino que es la cultura la que otorga esa significación mediante una convención que los miembros de la sociedad conocen; en nuestro caso, si tomamos como criterio esa aceptación de la gente hacia el significado del símbolo, veremos que, efectivamente, el traje de Montehermoso adquiere ese valor emblemático.

¿Cuáles son los símbolos de Extremadura? O mejor aún, ¿qué elementos culturales poseen una capacidad, aceptada por la gente, de representar y simbolizar a Extremadura? En nuestra sociedad, compleja y basada en un sistema mercantil, los símbolos son también un objeto de consumo, de manera que las personas no sólo se identifican o hacen uso de ellos, sino que además los compran. Veamos un ejemplo muy claro, para ello basta con dar un paseo por cualquier localidad extremeña y observar las llamadas vacas sagradas de nuestra cultura, es decir, los automóviles; si nos fijamos, las personas que poseen coches a veces los individualizan con determinados detalles decorativos que para el antropólogo pueden contener una valiosa información, y éste es uno de esos casos. ¿Cuáles son, de esos detalles decorativos, los que simbolizan a Extremadura y que los

15 E LEACH, Cultura y comunicación. La lógica de la conexión de los símbolos (Madrid: Siglo XXI, 1981 [1978]), 16-17. 
conductores colocan en sus automóviles a la vista de todo el mundo? Sin duda, el más usual es la bandera autonómica, bajo mil formas, como adhesivo, en una pequeña alforja de lana, en cintas de tela, etc.; esta bandera, los colores verde, blanco y negro no tienen ninguna relación objetiva con la región extremeña o con sus gentes, y sin embargo, tal como sucede con todas las enseñas de este tipo, es aceptada por la sociedad; representa a todo un pueblo que vive en una determinada región (o fuera de ella, pero que nació allí). En segundo lugar, en lo que a frecuencia se refiere, la figuración de una bellota se perfila también como uno de estos símbolos regionales; quizá fuera de nuestra región la asociación bellota-Extremadura no sea tan automática, pero para los extremeños está muy claro que el fruto de la encina puede representar perfectamente a su tierra: en los automóviles podemos ver colgadas pequeñas bellotas también de muchos tipos, de madera, de metal - muchas de ellas llevan un tapón a rosca que al abrirse deja ver una imagen de la Virgen de Guadalupe-, de plástico - a veces la forma es de bellota y los colores son los de la bandera autonómica-, etc. Y en tercer lugar, como símbolo de la región, en ocasiones se ven modelos a escala reducida de la gorra de Montehermoso; con este elemento sucede algo parecido a lo de la bellota, puesto que es más fácilmente identificable como símbolo por los propios extremeños que por los que no lo son; en general, este detalle no significa tanto "soy de Montehermoso" como "soy extremeño", puesto que no es difícil verlo en poblaciones muy alejadas de la citada población, $y$ es asimilado por quienes conocen la gorra como una señal de que el propietario del automóvil procede de aquella región. Si abandonamos el ámbito de los pequeños detalles decorativos - que son importantes, puesto que revelan el consumo de símbolos por la gente-, y pensamos qué otros elementos pueden simbolizar a Extremadura, sin duda el principal - junto a la bandera y la bellota- es la encina. En definitiva, encina y bellota son un todo que podríamos considerar como un símbolo único; la encina figura en el escudo de la Comunidad Autónoma de Extremadura, y numerosas guías turísticas, folletos, posters, etc., dedicados a Extremadura muestran un árbol de esta especie en su frontispicio; lógicamente, la encina, y su entorno natural, la dehesa, tienen una importancia capital en la vida tradicional extremeña, y de ahí viene su capacidad de simbolizar a toda la región; sin embargo, a nadie se le oculta que encinas -y dehesas- las hay en muchos lugares fuera de Extremadura, pese a lo cual esta región es, tal vez, la única que se considera representada por este árbol (no es casualidad que algunas personas llamen "belloteros" a los extremeños). Habría aún otros elementos susceptibles de ser utilizados como símbolo, tales como la imagen de la Virgen de Guadalupe, patrona 
de la región, la cigüeña, emblema que el gobierno autonómico está tratando de popularizar, el cerdo extremeño, debido a lo mucho que se aprecian los productos de la matanza ${ }^{16}$, $u$ otros no materiales, como alguna pieza musical claramente emblemática - no pienso en el himno regional, sino en los casos del Redoble o El Candil-, etc. Pero básicamente los símbolos más aceptados son la bandera, la bellota-encina y, en nuestra opinión, la gorra de Montehermoso.

Se comprobará que estamos ahora manejando la importancia simbólica de la gorra, y no del traje completo; efectivamente, la indumentaria adquiere aquí ese carácter emblemático no en su conjunto, sino por lo que respecta a uno solo de sus elementos, que es la gorra. ¿Por qué sucede esto? Sin duda, hay que buscar en la popularización de esta gorra un origen culto; es decir, que no ha sido el pueblo quien la ha dado a conocer y la ha convertido en una imagen familiar cuando se habla de Extremadura, sino que aquí se puede rastrear la intervención de eruditos e intelectuales que, desde el ámbito de la investigación, han llamado la atención sobre las particularidades de este aditamento.

\section{SOBRE LA GORRA DE MONTEHERMOSO}

En el clásico Manual de Folklore, don Luis de Hoyos y su hija Nieves distinguían una amplia zona peninsular que tenía como denominador común el tradicional uso por la mujer de sombreros de distintos tipos; esta área abarca desde León hasta Huelva, y parece tener su epicentro -y quizá origen- en la provincia de Ávila ${ }^{17}$. En todo caso, el uso de los sombreros, especialmente los de paja, es un fenómeno característico de la mitad occidental española, y parece cierto que en la provincia abulense se retrotrae en el tiempo a épocas bastante antiguas; así lo atestigua, al menos, la representación de unos graciosos sombreros en los sepulcros de una de las capillas de la Catedral de Ávila, fechados en el siglo $\mathrm{xv}^{18}$.

Nos interesa, pues, rastrear hasta donde sea posible el origen y el recorrido seguido por este detalle indumentario hasta su llegada a

16 Llama la atención el uso de este animal como símbolo que está teniendo lugar últimamente en las carreteras extremeñas, donde efigies en piedra marcan los cruces o desviaciones. Creemos que la importancia de este emblema -asimilable al binomio bellota-encina - va creciendo, impulsada por los poderes políticos, por la evidente implicación económica que posee, de modo que la crianza del cerdo de pata negra es claramente potenciada desde la Junta de Extremadura.

17 L. DE Hoyos SÁINZ y N. DE Hoyos SANCHO, Manual de Folklore (Madrid: Istmo, 1985 [1947]), 541-542.

18 Ibid., 542. 
Montehermoso. Primeramente conviene diferenciar de un modo muy claro lo que se considera sombrero y lo que entendemos por gorra: para ello, lo que cuenta es la anchura del ala, invariable y homogénea todo alrededor de la copa en el caso del sombrero, y menguante hacia atrás si se trata de la gorra ${ }^{19}$, dejando una abertura en la parte posterior para el moño. Partiendo de esta tipificación, encontramos gorras asimilables al tipo de Montehermoso en zonas amplias de las provincias de Ávila, Salamanca, Segovia y Cáceres, realizadas principalmente con paja de centeno, más adaptable al trabajo de trenzado que otros materiales.

En toda la zona que hemos referido se aprecia un conjunto de características comunes en el trabajo de las gorras de centeno, especialmente en la técnica de trenzado y en la práctica de combinar la materia vegetal con otras como cintas, espejos, lana, etc. ${ }^{20}$; en general, la gorra formaba parte del atuendo cotidiano de las mujeres, y su función principal era la de proteger del sol, quedando la posible finalidad decorativa en un segundo término. Lógicamente, pues, la gorra suele llevarse junto a una indumentaria de diario, y no de gala. Respecto a la decoración que suele ornamentar estas piezas, ya se ha dicho que es variable, pero la aparición del espejo parece que sólo se convierte en sistemática en Montehermoso; de hecho, las gorras de la provincia salmantina solamente lo incorporan como "caso extremo de ostentación" ${ }^{21}$, y las de Bohoyo (Ávila) por influencia de otras zonas, no pareciendo que sea una característica propia. En cuanto al color de las cintas o de la lana empleada en la decoración, la nota común es la observación del luto y la adecuación a la edad, de modo que las mujeres mayores - más que las viudas- suelen adornar su gorra con colores oscuros o negro, mientras las más jóvenes lo hacen con otros tonos más alegres. En cuanto a la forma de las gorras que aparecen en esta zona, la que predomina es la de ala plana y copa baja, con tendencia a la semiesfera, siendo el frente de la misma el lugar en que se concentra la mayoría de los elementos decorativos. Gorras parecidas al tipo que encontramos en Salamanca y Ávila, aparecen también en la provincia de Cáceres ${ }^{22}$, pero la gorra de Montehermoso, junto con su variante de Acei-

19 H. M. Velasco Mállo, "Apuntes para un estudio de la artesanía en Extremadura", Guía de la Artesanía de Extremadura (Madrid: Ministerio de Industria y Energía, 1980), 17-101.

20 C. MaRtín Benito, "Las gorras de paja de Bohoyo", Narria, 33 (1984), 20-27.

21 L GONZÁlez IGLesias, Nota sobre las gorras de rastrojera en la provincia de Salamanca», RDTP, I (1944-45), 136-138.

22 De Madrigal de la Vera es, por ejemplo, un modelo estudiado en C. MARTín BENTTO, op. cit., 21, y en el mismo Montehermoso existe -o existía - un sombrero llamado de "cama de liebre*, de ala ancha y plana que, por la descripción que de él tenemos, 
tuna, es probablemente el modelo más conocido dentro y fuera de la región; de hecho, la confección de esta gorra ha adquirido tal importancia que se ha convertido en toda una industria artesanal, de modo que ya en los años cuarenta de este siglo, las personas que confeccionaban gorras en la provincia de Salamanca habían aprendido el oficio, generalmente, en pueblos de Extremadura ${ }^{23}$.

Según parece, la tradición atribuye la introducción de la gorra en Montehermoso a "los moros", pero los datos que nosotros podemos manejar sitúan la llegada de la misma hace poco más de un siglo. Según Anderson, una artesana montehermoseña, llamada Máxima Hernández García, le había contado en los años treinta de este siglo que

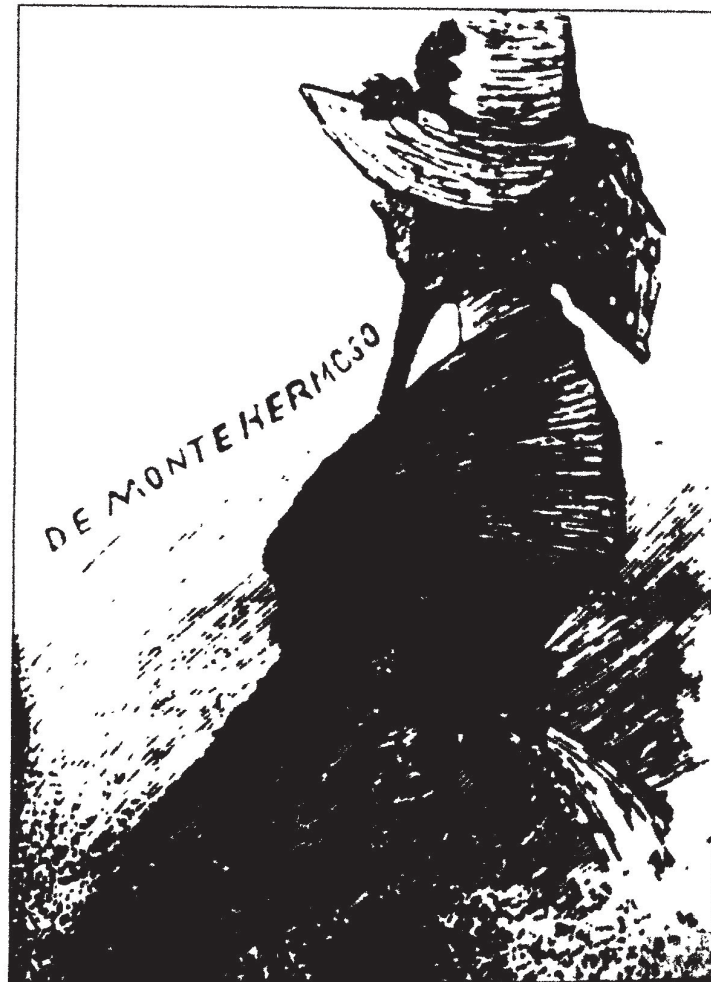

Fig. 1.-Primera representación gráfica conocida de la gorra de Montehermoso (1888). (La Ilustración Española y Americana, XLI: 262). fue su madre - más de cincuenta años antes- quien creó la gorra por adaptación, dándole una forma más atractiva a un sombrero que había llegado a este pueblo procedente de Villar de Plasencia, aunque seguramente originario de otro lugar. El modelo que había copiado la señora García era, desde luego, de paja, pero era "plano", y ésta lo reelaboró a su gusto, dándole una especial gracia ${ }^{24}$. Sus hijas, y otras artesanas, copiaron la simpática fórmula -que se popularizó rápidamente- y es así como, hace cuatro generaciones, nació la gorra de Montehermoso. Sea como fuere, la primera representación que conocemos de la gorra montehermoseña no es muy posterior a ese primer momento, puesto que data de 1888 (fig. 1). En realidad se trata de un dibujo muy esquemático, de la mano de Juan Comba, que publicó La Ilustración Española y Americana en su número XLI, página 262, correspondiente al 8 de noviembre;

parece aproximarse al modelo abulense: A. B. TALLÉs CRISTÓBAL, -Indumentaria de Montehermoso", Narria, 23-24 (1981), 42-48.

23 L GONZÁlez Iglesias, op. cit., 136.

24 R. M. ANDERSON, Spanish costume. Extremadura (New York: Hispanic Society of America, 1951), 120-121. 
el grabado carece de detalle, pero permite detectar una forma algo más plana que la actual, con la copa en una posición más vertical y una ausencia casi total de decoración, asemejándose ésta más a la de los tipos conocidos como "gorra de viuda". En definitiva, de este grabado de finales del siglo pasado se deduce una posterior evolución del modelo hacia formas y decoración con una mayor tendencia al barroquismo, curvándose hacia adelante la copa y recargándose la superficie de motivos ornamentales.

No es nuestra intención entrar a describir la gorra de Montehermoso, porque ya otros autores lo han hecho con anterioridad, y porque no es ése el tema que nos interesa; sólo diremos que entre los investigadores no existe un total acuerdo acerca de la tipología observable: Hoyos Sancho distingue cuatro tipos, que serían la gorra de diario, la guapa o de soltera, la de casada y la de viuda ${ }^{25}$; Velasco y Tallés, cada uno por su lado, se limitan a diferenciar la de soltera, la de casada y la de viuda. En todo caso, lo que distingue al tipo cacereño de las otras gorras de centeno de Ávila y Salamanca es el vuelo que adquiere el ala en su parte anterior, y la inclinación hacia adelante de la copa; morfológicamente sólo existe una gorra, siendo las variedades apuntadas en función de la decoración que presenta cada una de ellas. El elemento esencial escogido por los autores para establecer la diferenciación de la gorra correspondiente a cada uno de los status de su propietaria es la presencia -0 no- de un pequeño espejo circular en su parte frontal, pero tampoco en esto hay una total coincidencia: según Hoyos Sancho, el espejo aparece en la gorra de soltera, y no existe en la de casada ni en la de viuda, pero autores como Muñoz de San Pedro dicen que las viudas lo vuelven a poner, aunque roto ${ }^{26}$.

En realidad, la presencia del espejo se justifica por una utilidad bien concreta: la gorra es un tocado reservado para las tareas diarias, se utiliza para salir al campo, y por ello la moza puede utilizar el espejito para acicalarse durante o después de las tareas agrícolas. El hecho de que muchas casadas no lleven el espejo se explica - los montehermoseños así lo sostienen - porque el uso prolongado de la gorra termina con su deterioro o la rotura del espejo, y la mujer casada - menos necesitada y tendente a la coquetería - ya no lo repone. No es cierto, según nuestros

25 N. DE HOYOS SANCHO, "El traje regional de Extremadura", RDTP, XI (1955), $155-177$ y $353-385$

26. M. MUNOOZ DE SAN PEDRO, Extremadura (la tierra en la que nacian los dioses) (Madrid: Espasa-Calpe, 1961), 93. Siguiendo a este autor merece mencionarse un interesante trabajo que aborda el tema sin intención de profundizar en él: M. A. GonzÁlez MENA, "Las artes textiles populares cacereñas", Revista de Estudios Extremeños, XLVI, 1 (1990), 9-86. 
informantes, que el hombre rompa el espejo de su mujer el día de la boda para que ningún otro pueda verse en él, ni mucho menos que la ausencia del mismo signifique la pérdida de la virginidad.

Respecto a la gorra de viuda, se diferencia de las otras en que el color de la decoración -que además es más austera- es preferentemente negro, pero conviene señalar que esta gorra no implica necesariamente la viudedad, sino, sobre todo, el luto. Las mujeres que guardaban luto, o aquellas que, simplemente por su avanzada edad, vestían de negro, llevaban esta gorra, ya que se consideraba más adecuada al resto de la vestimenta. En general, el atuendo de las montehermoseñas enlutadas presenta como única nota de color las características medias azules que, junto a las mantillas de color negro, todavía siguen utilizando.

A la vista de todo esto se puede ya obtener una deducción, y es que existe una especie de tradición en la producción literaria - y también científica- que considera indiscutible el hecho de que el espejo simboliza la virginidad, y que el uso de la gorra ha adquirido "funciones peculiares en los ritos festivos, e incluso en el ritual de bodas, donde el paso de soltera a casada era simbólicamente marcadon ${ }^{-}$. No es de extrañar que esta interpretación haya ganado adeptos, puesto que plantea un tema tan subyugante para el antropólogo o el literato como es que la mujer lleve escrito, casi en su misma cara, el estado de su virginidad. Nos inclinamos a pensar que tal extremo carece de una base cierta; primeramente porque esta versión de la historia es completamente rechazada por los habitantes de Montehermoso, que cuentan cómo muchas casadas seguían llevando el espejo hasta que se rompía o encargaban otra gorra, pero también porque -aunque efectivamente se han empleado signos externos que explicitan el estado matrimonial- es difícil pensar que la mujer pueda proclamar la pérdida de su virginidad en una sociedad de la Europa meridional, en la que conceptos como bonor o vergüenza han sido reiteradamente identificados como aspectos esenciales de la cultura ${ }^{28}$, y donde además, al menos tan importante para la mujer como ser virtuosa, es aparentar que lo es.

Por último, hay una cuestión que, por otro lado, nos va a permitir enlazar con el próximo apartado, y es que la importancia indumental de la gorra fue siempre secundaria, como pieza del traje cotidiano, y que difícilmente pudo estar en el centro de algo tan importante como es un ritual de bodas, marcando el paso a un nuevo status, por una razón bien

27 H. M. VELASCO, op. cit. (1980), 73.

28 S. BRANDES, "En torno a los conceptos de honor y vergüenza", L. DIAz Viana (ed.), Etnología y folklore en Castilla y León (Salamanca: Junta de Comunidades de Castilla y León, 1986), 21-30. 
sencilla: que el traje de novia montehermoseño se caracteriza, precisamente, porque la mujer no se cubre con la gorra, sino solamente con un pañuelo.

\section{VARIABILIDAD DEL TRAJE DE MONTEHERMOSO}

Ya apuntábamos en las primeras líneas de este trabajo que un aspecto de la indumentaria tradicional que nos parece esencial es el de su variabilidad a lo largo del tiempo y del espacio. El conocimiento de estos procesos es difícil ya que, en muchas ocasiones, no disponemos de trajes lo suficientemente antiguos como para documentar una evolución en los tipos; es algo, sin embargo, que debe, al menos, intentarse no sólo porque nos informará sobre aspectos formales de la indumentaria, sino también porque puede ayudarnos a rastrear casos de tradiciones aceptadas por todo el mundo pero que en realidad no son tales, es decir, tradiciones inventadas. Esto es lo que, en nuestra opinión, sucede con algún aspecto del traje femenino de Montehermoso, como vamos a tratar de argumentar.

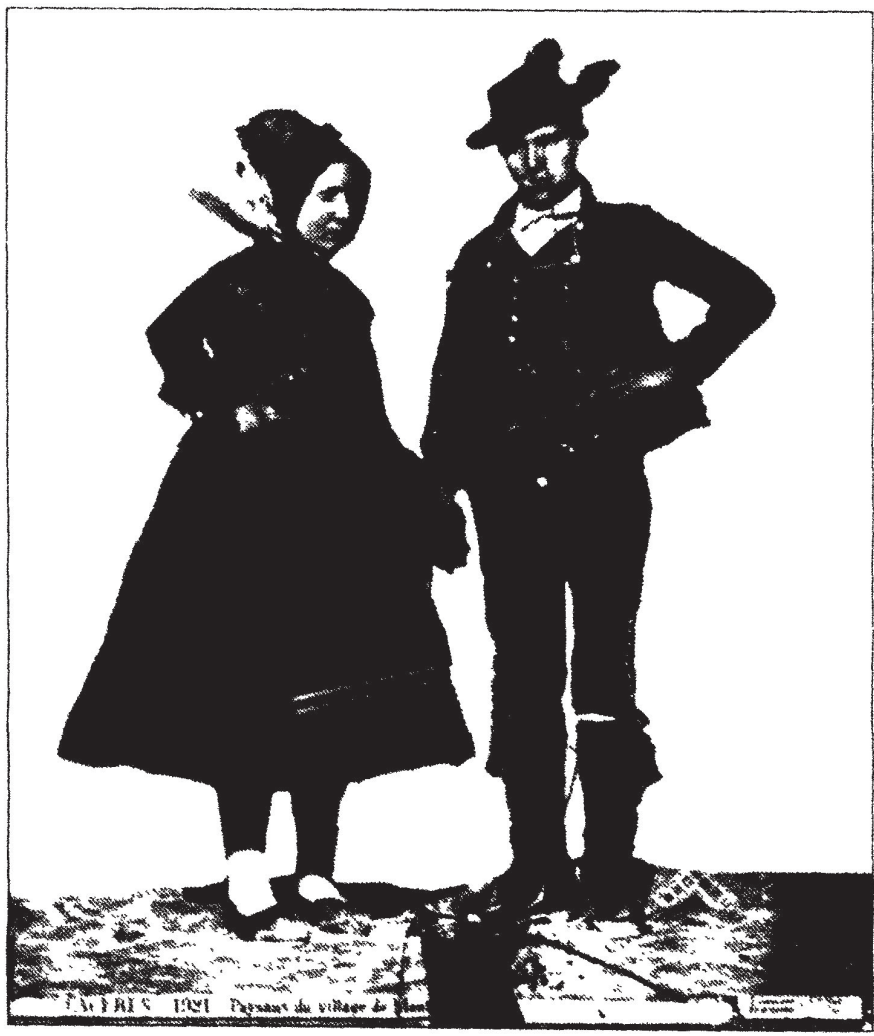

FIG. 2.-Pareja de aldeanos de Montehermoso en traje de gala (1878). (Fotografía Laurent. Fototeca del Patrimonio Histórico. Archivo Ruiz Vernacci. ICRBC. Ministerio de Cultura).

Para intentar seguir una posible evolución formal del traje de mujer montehermoseña, hemos procurado estudiar algunos casos concretos de distintas épocas y procedencias; ya sabemos que, al haber adquirido este traje -a través de la gorra- un carácter simbólico, su uso ha desbordado los límites de la comunidad montehermoseña, y por tanto es utilizado -y confeccionado- en otras localidades de la región e incluso fuera de ella. Así, dentro de la serie de trajes a que nos vamos a referir, algunos han sido realizados - total o parcialmente- fuera de Extremadura, aunque los otros proceden indudablemente de la pobla- 
ción de Montehermoso. En concreto, hemos seleccionado cinco trajes, con fechas ante quem más o menos seguras, de los que se cita además la procedencia, para comprobar los cambios que se han podido operar a lo largo del tiempo. En todos los casos se trata de trajes de gala o de fiesta, si bien se aprecian diferencias que vamos a ir desgranando.

El primer caso que veremos es el traje de mujer que lució una anónima bailarina que formaba parte de la comparsa de Montehermoso llegada a Madrid a finales del mes de enero de 1878 para participar en las celebraciones que tuvieron lugar con motivo de la primera boda del rey Alfonso XII (fig. 2). En aquella ocasión, la Diputación Provincial de Cáceres organizó la expedición de todo un grupo de músicos y bailarines que obsequiaron a los reyes y al pueblo de Madrid con sus danzas "2; su estancia en la capital de España fue un acontecimiento social de primera magnitud, pues se trata quizá de la primera ocasión en que fue posible admirar juntos los trajes y bailes de gran parte de las provincias españolas; la gente se lanzó literalmente al Paseo del Prado, donde se habían instalado las comparsas de las provincias, con la intención de ver y tocar a sus componentes, llegando a provocar incluso problemas de orden público ${ }^{31}$. Desgraciadamente, ya no disponemos del traje que aparece en la fotografía de Laurent, y nuestro estudio debe limitarse a aquellos aspectos formales externos que son visibles en la imagen; lógicamente se trata de una fotografía en blanco y negro, por lo que no es posible establecer con exactitud los colores. No obstante, conocemos la descripción que la prensa madrileña hacía de este traje con ocasión de las bodas reales:

29 Según consta en el Acta de la Sesión celebrada por la Comisión Provincial, con fecha 7 de enero de 1878 :

Para celebrar el anunciado enlace de S.M. el Rey con su ilustre prima la infanta Doña Mercedes, y como débil muestra del regocijo que la leal provincia de Cáceres siente por tan feliz acontecimiento, se acuerda sin perjuicio de dar en su día cuenta á la Diputación. (...) Enviar seis parejas de ambos sexos de vecinos de Montehermoso para contribuir con la exhivición (sic) de sus trajes característicos y típicos de gran parte de la provincia á las funciones y festejos que han de tener lugar en la Corte con tal motivo. Para acompanarlos, alojarlos y suministrarles lo necesario para su sostenimiento, se designa al empleado de la Diputación Don Santiago González, a quien se le satisfarán los gastos que se le originen en el desempeño de esta Comisión.

(No podemos dejar de manifestar nuestro agradecimiento por esta información a los funcionarios del Archivo-Biblioteca de la Diputación Provincial de Cáceres).

30 A. Gutiérrez, Aportación para el estudio de la indumentaria española. Fotografías de J. Laurent. siglo XIX", Conferencia Internacional de Colecciones y Museos de Indumentaria (Madrid: Museo Nacional del Pueblo Español, 1993), 143-157. 
La de Cáceres la forman parejas del pueblo de Monte-Hermoso. El traje de las mujeres consiste en pañuelo de seda de color á la cabeza, esclavina de paño rodeada al talle con adornos, jubón de terciopelo, manga estrecha con botonadura de plata y vueltas de terciopelo de color, guardapiés plegado, mandil de cúbica, medias negras ó azules, según sean casadas o solteras, y zapatos de orejilla con hebilla de plata ${ }^{31}$.

Lo primero que nos llama la atención, y que conviene resaltar aquí es que, en el ejemplo más antiguo que presentamos, que procede ciertamente del mismo pueblo montehermoseño, no aparece la célebre gorra. No olvidemos que faltan diez años para que la prensa reproduzca por primera vez este tocado ${ }^{32}$, pero esto no excluye la posibilidad de que ya se utilizara; en cualquier caso, es preciso recordar que la gorra es un elemento propio del traje de diario, se trata de un aditamento esencialmente utilitario, por lo que el traje de gala, como debe ser el que se vista ante los Reyes de España, de ningún modo puede incluirla. En otro orden de cosas, destacaremos que, en la descripción y en la fotografía que reproducimos, aparecen ya fijadas las que van a ser características esenciales del traje femenino de Montehermoso, como podremos comprobar más adelante. No aparecen, sin embargo, la faltriquera y el pañuelo, y el adorno es bastante parco en la vuelta de las mangas del jubón.

Si pasamos al segundo de los ejemplos escogidos, se trata de un traje que debe fecharse un máximo de cincuenta y siete años después del que hemos visto, aunque ya sabemos que una datación exacta, en este caso, no es posible. Es el traje que figura en la colección del Museo Nacional de Antropología, y cuya procedencia parece que corresponde al mismo pueblo de Montehermoso, si bien dicha información no consta. Por desgracia, parece que la documentación del Museo no conserva referencia alguna a la llegada de este ejemplar, y los libros de registro sólo dan el escueto dato de la entrada de "Un traje por compra de mujer casada de Montehermoso", siendo la fecha del asiento el año 1935. En contra de lo que habíamos supuesto en un principio, no parece que este traje forme parte del primitivo bloque que constituyó el germen del Museo del Pueblo Español; como es sabido, aquellas primeras series procedían de numerosas donaciones y compras efectuadas sobre los materiales que habían figurado

31 La Época, 26-I-1878, 2.

32 En un grabado fechado en 1881, alegórico de la provincia de Cáceres, se representa el traje de Montehermoso con una larga mantilla y la consabida esclavina, pero en este caso la mujer todavía no se cubre la cabeza con la gorra ni tampoco con el paǹuelo. [Gran Enciclopedia Extremeña (Mérida: Ediciones Extremeñas, S.A., 1991), IV, 99]. 


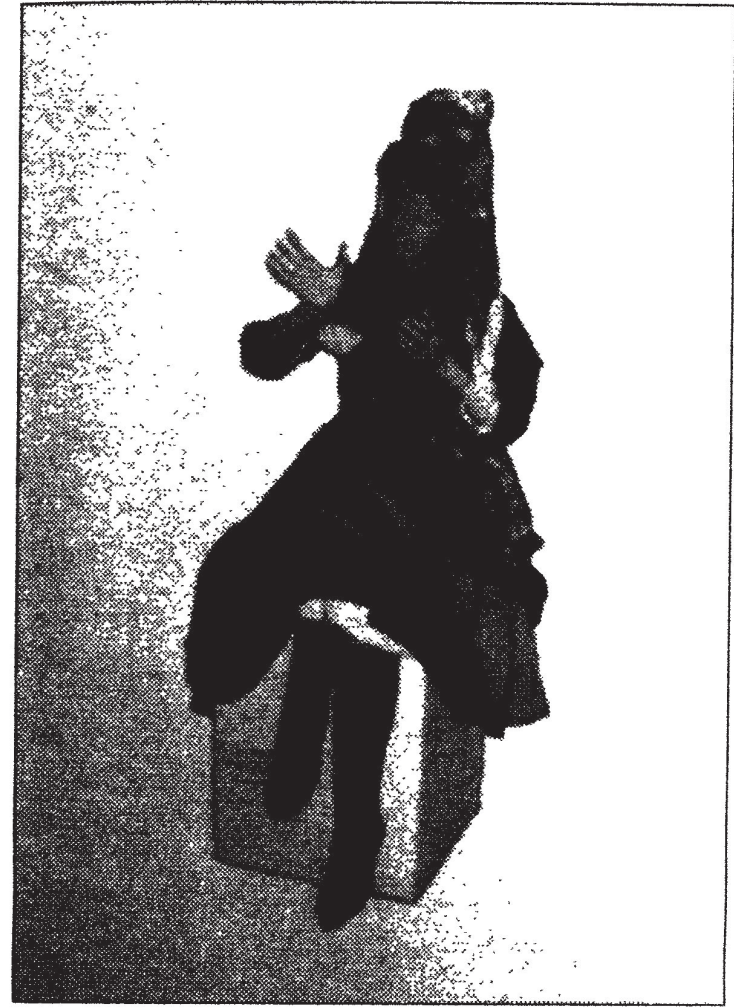

FIG. 3.-Traje de mujer de Montehermoso de la Colección Ismael Peña. en la Exposición del Traje Regional de $1925^{33}$, y que posteriormente pasaron al Museo del Traje Regional e Histórico, para terminar formando el origen del Museo del Pueblo Español ${ }^{34}$. En cualquier caso, no parece aventurado pensar que este ejemplar sea uno de los estudiados por Nieves de Hoyos en su trabajo - ya citado- sobre la indumentaria extremeña. El ejemplar del antiguo Museo Nacional del Pueblo Español, a que nos venimos refiriendo, figura como un traje "de mujer casada", y esto es ya un dato de importancia, pero lo que más nos interesa es constatar que en el registro de entrada del Museo no se hace referencia a la gorra, de modo que el atuendo ingresó sin este tocado, que le fue añadido con posteriori-

dad. En otro orden de cosas, de la fotografía que ilustra la ficha del Museo llama la atención la ausencia de joyas, así como de detalles como el pañuelo o la faltriquera, y la pobreza de los zapatos.

33 Sabemos, sin embargo, que en aquella Exposición figuró un traje de fiesta de montehermoseña [Exposición del Traje Regional. Guia (Madrid: Imprenta de Artes de la Ilustración, 2." ed., 1925), 48], pero no disponemos de más referencia documental ni gráfica sobre aquel indumento. Un trabajo posterior de Hoyos Sáinz, que recoge numeroso material procedente de aquella muestra, reproduce una fotografía correspondiente a una pareja de Montehermoso que en nuestra opinión es muy probablemente la que figuró en la Exposición. En esa imagen, el traje femenino aparece con la gorra de soltera con espejo, faltriquera y las mantillas relativamente cortas, algo por debajo de las rodillas; no se adorna con las clásicas joyas torrejoncillanas [L. DE HOYOS SÁINZ, El método etnográfico en el estudio de la indumentaria regional de España (Madrid: Asociación Española para el Progreso de las ciencias, 1929), 81-99]. Si se acepta nuestra hipótesis, el añadido de la gorra al traje de gala podría haber quedado consagrado tras esta gran exposición de 1925 nada menos que con el beneplácito de don Luis de Hoyos; en este sentido cabe recordar que puede no ser casual el que en la comisión que seleccionó el material extremeño para la muestra figuren pintores como Covarsí y Hermoso y literatos como Chamizo y Reyes Huertas, más próximos al casticismo de Sorolla que al cientifismo de Hoyos.

34 C. ORTIZ García, “Contribución de la Escuela Superior del Magisterio al estudio del traje regional español (1914-1936)n, RDTP, XLIII (1988), 445-455. 


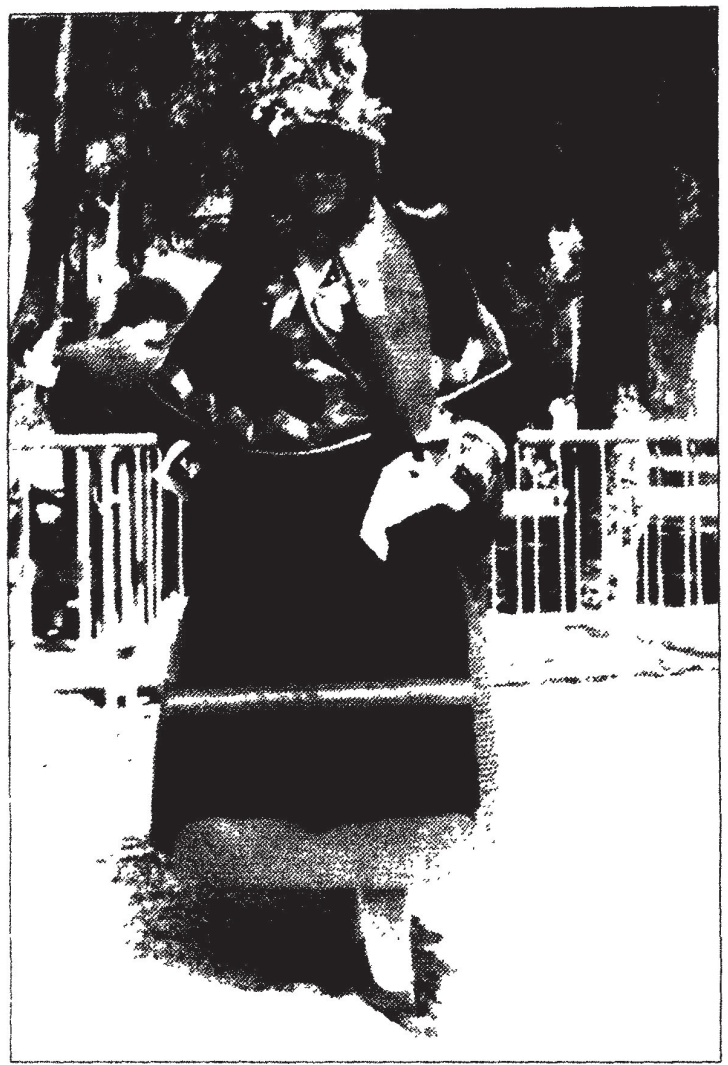

Fici 4.-Traje de montehermoseña de los Coros y Danzas de la Casa de Extremadura de Leganés.
En cuanto a nuestro tercer ejemplo, referiremos que se trata de un traje que pertenece a una colección particular, concretamente a la del conocido cantante y folklorista Ismael Peña (fig. 3). Sin duda es el ejemplo más heterogéneo e inseguro de cuantos traemos aquí en cuanto a datación y origen, ya que no fue adquirido completo, sino por piezas. Empezando de arriba hacia abajo, la gorra procede realmente de Montehermoso y fue comprada hace alrededor de veinte años, mientras que la esclavina sí que es más antigua, sin que podamos precisar más, pero fue adquirida en Salamanca. El jubón, de traza y confección sencilla, es también de los años setenta, lo mismo que la faltriquera y las medias; todo ello tiene una procedencia incierta que no excluye la población montehermoseña. Sin duda lo que es más antiguo, junto con la esclavina, son las sayas, ciertamente valiosas, pero en cuanto a su origen, nada hay seguro, pues alguna fue comprada en Cáceres, pero otras lo fueron en el Rastro madrileño ${ }^{35}$. De este traje, lo que resalta es, desde luego, su condición de mescolanza, en tanto que las piezas son de diferentes épocas y procedencias, y muestra además una evidente heterodoxia en lo que se considera la forma pura del traje montehermoseño, ya que incluye la gorra cuando las sayas de color madre de vino nos están hablando de un traje de gala. Por otro lado, el jubón no tiene nada que ver con el de gala de Montehermoso, y más que una muestra pobre nos inclinamos a pensar que se trata de una pieza de otro traje distinto del cacereno; algo parecido podría decirse de la desmesurada faltriquera.

El siguiente ejemplo que hemos escogido es un traje totalmente confeccionado fuera de Montehermoso, a excepción de la gorra, y dentro de los modelos que podemos encontrar fruto de la expansión de esta indumenta-

35 A la amabilidad de su propietario debemos la autorización para publicar aquí las fotografias y también los datos acerca del origen de dichas ropas, lo que agradecemos muy sinceramente. 


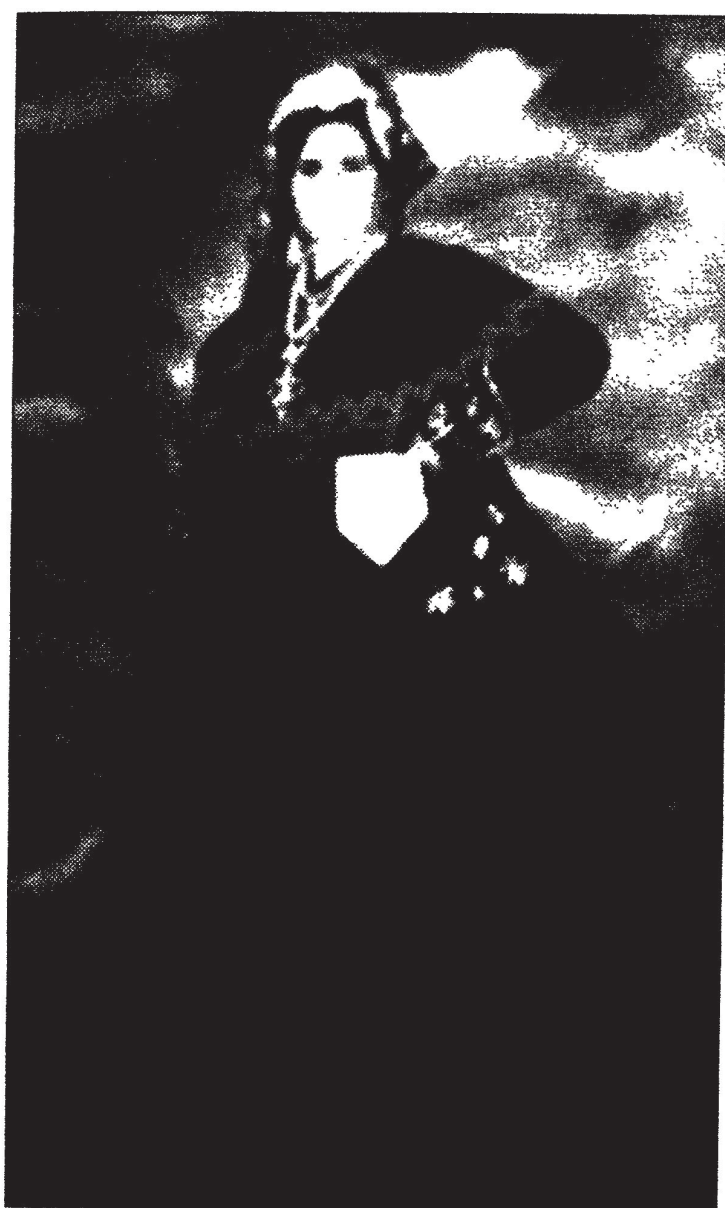

FIG. 5.-Traje actualmente elaborado en Montehermoso. (Cortesía de Dña. Antonia Hernández Gil).

ria - a causa de su valor simbólicoes de los más fidedignos (fig. 4). Se trata del traje femenino utilizado por un grupo de Coros y Danzas establecido fuera de Extremadura, y confeccionado por las propias jóvenes que lo visten con motivo de su participación en festivales folklóricos ${ }^{36}$. Por tratarse de un traje concebido para el baile, llama la atención que el número de sayas es corto -dos-y que los zapatos no son los característicos "de oreja de ratón", pero en general se reproduce con bastante dignidad el modelo montehermoseño. Pequeños detalles, como la mantilla de color madre de vino y cortapisa de amarillo "dominguero", las cintas de atrás bordadas — "de los señores" - y la riqueza de las vueltas en las mangas del jubón nos están hablando de un traje festivo, mientras que la presencia de la gorra responde a esa desvirtuación que ya hemos visto de añadir este tocado al vestido de gala.

En cuanto al último de los trajes que hemos podido estudiar, se trata del que todavía se realiza en la localidad de Montehermoso, hecho por tanto en nuestros días y en el punto de origen del tipo indumentario (fig. 5). Como se puede ver, es el que ofrece una imagen más aproximada a la de la fotografía de 1878, siendo de destacar la longitud de las mantillas, que ahora se han acortado respecto a las del siglo pasado (fig. 6). A este respecto, conviene resaltar las opiniones vertidas por distintos estudiosos del tema, que han calificado a la de Montehermoso como la "saya más corta de España", atribuyendo a esta característica un origen tradicional; las imágenes que ofrecemos no dejan lugar a dudas sobre este punto,

36 Se trata del traje de Montehermoso confeccionado y exhibido por el grupo .Villa de Leganés" perteneciente a la Casa de Extremadura de esta ciudad madrileña. Hay que decir que, dentro de la tónica de estos grupos de coros y danzas, el que hemos escogido se caracteriza por un rigor por encima de lo habitual, tanto en la selección de las piezas folklóricas a interpretar como en la confección de los trajes. 


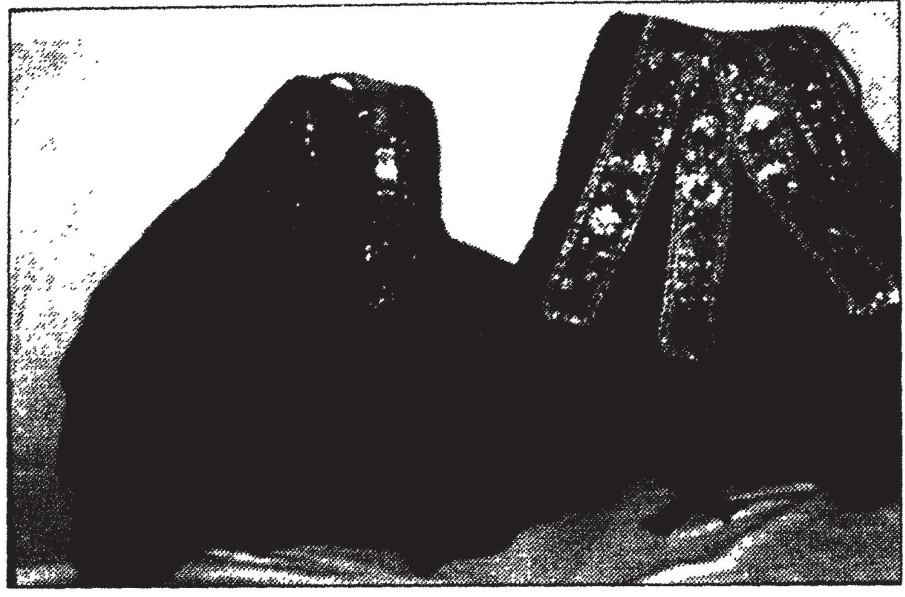

FIG. 6.-Mantillas del traje de Montehermoso adornadas con cintas de señores. (Cortesía de Dña. Antonia Hernández Gil).

y muestran bien a las claras que en esta población cacereña la longitud tradicional de las sayas (aquí "mantillas") no es tan reducida como se ha pretendido, sino que es en los últimos cien años cuando se ha ido acortando; de hecho, en Montehermoso, como en otros pueblos españoles, la mujer ha llevado sayas por debajo de la rodilla, puesto que se consideraba atrevida, o incluso ridícula ("payasa"), a la mujer que las llevara más cortas ${ }^{37}$.

Volviendo al modelo a que nos referimos ahora, resaltan el pañuelo bordado y la faltriquera (fig. 7), que no aparecen en la foto de Laurent. La joyería con que se enriquece el vestido, ausente en los modelos tercero y cuarto, es la que se usa desde hace generaciones en la población, la célebre "cruz de pingallo" de Torrejoncillo -que en ocasiones se alterna con la otra forma conocida como "galápagom y que ya era utilizada en 1878 , como se ve en ta fotografía de ese año. Se trata, pues, de un vestido de fiesta, de lujo, no precisamente de novia, pues en este caso la mantilla exterior sería negra, pero sí de gala, y por ello no incluye el uso de la gorra ${ }^{3 *}$.

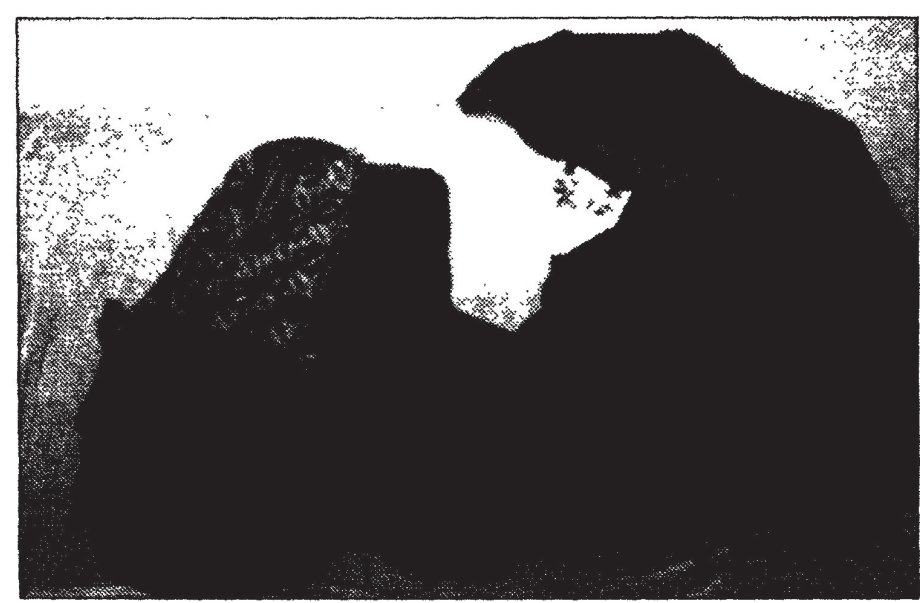

FIG. 7.-Faltriquera, mantillas, pañuelo y jubón del traje de montehermoseña. (Cortesía de Dña. Antonia Hernández Gil).

3- Esta información, como muchos otros datos que se incluyen en el texto, se debe al testimonio de nuestro informante, don Abundio Pulido, gran conocedor de todos los aspectos de la indumentaria de Montehermoso y director del grupo folklórico "Sabor Añejö, al cual manifestamos desde aquí nuestro agradecimiento.

38 Debemos agradecer toda esta información a doña Antonia Hernández Gil, que tuvo la amabilidad de recibirnos en su casa y mostrarnos los diversos componentes de 
En resumen, se aprecia que efectivamente hay una variabilidad en el tiempo y en el espacio: a grandes rasgos, diremos que la imagen más usual del traje festivo de la montehermoseña ha incorporado ya la gorra, lo que no tiene nada que ver con que éste sea un elemento ortodoxo o del traje puro. Sólo en el propio Montehermoso se sigue confeccionando y vistiendo - en las grandes ocasiones - la indumentaria como fue, y sobre este punto aún cabe insistir en que la gorra nunca formó parte del traje de fiesta, como lo atestiguan los lugareños y numerosos trabajos científicos bien documentados: por ejemplo, la fotografía que Anderson publica en la página 161 de su trabajo ${ }^{39}$, correspondiente el baile de carnaval de 1949 , muestra la plaza de Montehermoso atestada de gente, con atuendo de gala, y ni una sola mujer lleva la gorra. Otro ejemplo: los trajes de mujer de esta población que se conservan en el Museo de Cáceres, adquiridos a don Pedro Pérez Enciso en 1972 , no tienen gorra en aquellos casos en que se trata de vestidos de novia (802 y 803) o de madrina (1.091), mientras que sí la llevan los números 1.089 (de luto) y los números $1.092,1.097,1.098,1.100$ y 1.101 , todos ellos de diario ${ }^{40}$. Una última llamada de atención: un breve repaso a la fotografía en que Sorolla posó junto a sus modelos durante la estancia en Plasencia, permite darse cuenta de que sólo llevan gorra las dos mujeres vestidas de diario, mientras que las ataviadas de fiesta (una niña y una mujer adulta) van sin tocado y con el pañuelo de colores respectivamente ${ }^{41}$.

Junto a este detalle de la gorra, otra variación que se observa es la del progresivo acortamiento de las mantillas, a que ya nos hemos referido; queda claro que ésta es una evolución propia -que podríamos llamar interna- del traje, por cuanto ha afectado también a los que se realizan dentro de la población. Otras modificaciones corresponden ya a esa expansión del traje fuera de los límites de la localidad, y aquí vemos que hay grandes cambios en determinadas piezas del traje, como los zapatos, la esclavina, el jubón, la faltriquera, etc., y todo ello sin entrar a juzgar

\footnotetext{
la indumentaria montehermoseña. La señora Hernández es, en 1993, la única artesana que todavía confecciona los trajes completos - salvo la gorra-siguiendo las técnicas heredadas de las anteriores generaciones, aunque realmente tiene muy pocos encargos al tratarse de prendas muy caras cuyo uso ha decaído bastante; así, hace unos cuatro o cinco años que no ha tenido lugar una boda con los atuendos típicos del pueblo. Por lo que respecta a las gorras, sí que existe un mayor número de personas especializadas en su confección, puesto que se trata de un producto que tiene una mayor salida comercial al ser requerido por bastantes turistas.

39 R. M. ANDERSON, op. cit. (1951).

40 M. A. González Mena, Museo de Cáceres. Sección de Etnografía (Madrid: Ministerio de Educación y Ciencia, 1976), 159-162.

41 R. M. ANDERSON, op. cit. (1951), 160.
} 
los materiales con que se confeccionan. Sin duda se aprecia un proceso evolutivo en que corren parejos varios fenómenos, como son la expansión del traje fuera de Montehermoso, la introducción de la gorra -acompañada por esa leyenda del espejito- en el atuendo festivo, el acortamiento de las mantillas y la adquisición del carácter de símbolo regional. En nuestra opinión, se trata de un proceso que se retroalimenta, es decir, que las peculiaridades - reales o inventadas - hacen que se convierta en emblema y, a la vez, la condición de símbolo hace que la vestimenta sobrepase las fronteras de la población y se introduzcan modificaciones que tienden a potenciar esas peculiaridades.

\section{LA INVENCIÓN DE UNA TRADICIÓN}

Más arriba tuvimos ocasión de comprobar que el uso de la gorra de Montehermoso puede tener un origen espaciotemporal bien concreto; puede tratarse de una importación realizada a finales del siglo xIx, y por lo tanto tratarse de un elemento indumentario que no tiene la antigüedad que se ha pretendido. También hemos hablado algo sobre la cuestión del espejo que se supone llevaban las solteras y no las casadas (o sí, pero roto), y hemos argumentado en contra de que esa supuesta tradición fuera realmente como se nos ha querido presentar. Hemos visto también cómo, precisamente por esas circunstancias que rodean a la gorra, y también porque se considere a las sayas del traje montehermoseño como "las más cortas de Españan, esta indumentaria ha podido devenir un símbolo de la región extremeña, a pesar de que dentro de ella constituye en realidad "no una variación comarcal, sino un tipo de traje diferente" ${ }^{42}$. Ahora bien, sabemos que todos esos extremos son, cuando menos, discutibles, de manera que será provechoso comprobar a través de qué proceso se ha producido esa conversión del traje montehermoseño en todo un símbolo regional.

Resulta que tenemos ante nosotros un símbolo que encarna toda una tradición de apariencia antigua y venerable, pero que realmente tiene poco más de cien años. Así que se trata, por lo menos, de una tradición reciente, pero, ¿es realmente una tradición?

Podemos observar que ese vínculo con un pasado histórico es realmente ficticio, no existe; se trata, por tanto, de la referencia a una situación antigua como respuesta a una situación nueva. Tal vez parezca excesivo referirse a la invención de esta tradición, pero creemos que es esto precisamente lo que ocurre en este caso, y vamos a tratar de razonarlo.

42 N. DE HoYOS SANCHO, op. cit. (1955), 368. 
Se entiende por tradición inventada una serie de prácticas, normalmente gobernadas por unas reglas aceptadas explícita o tácitamente, y un ritual de naturaleza simbólica que intentan inculcar ciertos valores y normas de comportamiento por repetición, lo que implica automáticamente continuidad con el pasado ${ }^{43}$.

En nuestro caso, disponemos de los ingredientes para preparar ese guiso de la tradición inventada, puesto que existe la práctica (la colocación del espejo), las reglas que la gobiernan (el control social sobre la virginidad) e incluso el ritual (utilización de este elemento incluso fuera de su ámbito como indumentaria cotidiana, invasión del terreno de lo festivo). Tenemos, además, la pretendida continuidad respecto del pasado, puesto que se presenta la costumbre como la huella de una larga tradición. No cabe duda, sin embargo, de que la finalidad de esta tradición inventada es un objetivo nuevo, actual, que no tiene relación con el momento histórico del que se quiere hacer arrancar la práctica. Acerca de los objetivos de las tradiciones inventadas se ha dicho que éstos pueden ser de tres tipos distintos, pero que a la vez se superponen entre sí: la simbolización de una cohesión social o pertenencia a un grupo, la legitimación de las instituciones o los status sociales y la socialización del individuo, a través de la inculcación de creencias y modos de comportamiento.

No creemos que haya que interpretar esta tradición inventada como un esfuerzo de la sociedad por lograr la regulación de la conducta sexual de la mujer, al menos no desde el momento en que el símbolo sobrepasa los límites de la comunidad, sino sobre todo como una forma de aportar a la provincia de Cáceres, y últimamente a la región extremeña, un indicador cultural válido para constituir un símbolo regional. Como se sabe, en Extremadura no ha habido un nacionalismo fuerte, siendo incluso arriesgado hablar de una tradición regionalista que, si bien ha existido, su influencia en las clases dominantes, con capacidad decisoria, ha sido bastante débil; no tiene, pues, esta región un corpus simbolicum articulado que pueda servir para la autopercepción como pueblo, de manera que con el tiempo ha sido preciso seleccionar algunos aspectos culturales y dotarles de un valor simbólico que permitiera la identificación étnica.

Ya hemos visto más arriba algunos de los elementos que hoy día son utilizados como símbolos de la región, pero si nos centramos ahora en la tradición de la gorra y la corta saya montehermoseña, concluiremos que la invención de esta tradición ha supuesto la incorporación de uno de los

43 E. J. HobsBawm, -Introducció. L'invent de les tradicions", E. J. HobsBawm y T. RANGER (eds.), L'invent de la tradició (Barcelona: Eumo Editorial, 1988), 13-25. 
más antiguos símbolos de nuestra región. Se trataba de cimentar la cohesión de una comunidad que estaba fuertemente desarticulada (hace cien años Extremadura no existía como región judicial, ni militar ni eclesiástica) y que además carecía de indicadores de una especificidad cultural (el propio santuario de Guadalupe, epicentro del extremeñismo religioso, pertenece todavía hoy a la Diócesis de Toledo), de manera que poco a poco se fue generando la creencia en una tradición que sí era genuinamente extremeña, y que difícilmente podría tener un paralelo en otras regiones españolas. Así, con el objeto de conseguir un fin nuevo - la manifestación de una identidad cultural de reciente cuño- se ha utilizado un repertorio material antiguo, logrando que las peculiaridades de este traje y su gorra hayan sido un símbolo de Extremadura mucho antes de que en esta región se hablara de autonomía o de que se diseñaran su bandera, su escudo y su himno. Seguramente, se han escogido estos detalles del traje por lo que tienen de pintoresco o exótico para el culto investigador del medio urbano; se trata, pues, de ensalzar aquello que, por diferenciarse más radicalmente de lo ciudadano, se considera genuinamente rural, quizá vestigio de un ideal pasado en el que lo extremeño se podía encontrar. en su estado prístino, sin las homogeneizadoras influencias cultas procedentes de la ciudad. En este sentido, nos encontramos ante una tradición inventada que ha venido cumpliendo la función de conseguir la sensación de pertenencia a un grupo que sobrepasa los límites de la comunidad local (Extremadura), y que además ha desempeñado el papel de legitimar unos supuestos usos y costumbres específicos de la región, y por lo tanto diferenciables de los conocidos en Castilla o Andalucía, las dos entidades sociopolíticas frente a las que Extremadura trata siempre de distinguirse con el objeto de fundamentar su propia regionalidad.

\section{Juan Manuel Valadés Sierra Museo Nacional de Antropología Madrid}

\footnotetext{
La indumentaria, como otros aspectos de la cultura, se halla sujeta a la variabilidad en tiempo y espacio, de manera que el estudio de los modos de vestir tradicionales debe abordarse desde una perspectiva diacrónica y teniendo en cuenta las modificaciones que aparecen cuando los trajes desbordan sus límites comunitarios. Por otro lado, determinados modelos indumentales pueden llegar a convertirse en símbolo de una comunidad específica, forjándose entonces una imagen estereotipada de ellos que coincide con lo que se considera como la versión auténtica del traje. En el caso de Extremadura, y a falta de otros indicadores culturales válidos, el traje de la mujer de Montehermoso
} 
(Cáceres) llega, pues, a convertirse en símbolo regional, partiendo de la manipulación y distorsión de sus elementos formales tradicionales para la consecución de una imagen específica y diferencial, proceso que podemos considerar como la invención de una tradición.

Clothing, just like other aspects of culture, is subject to variability in time and space, so that the study of traditional ways of dressing should be made from a diachronous perspective, and bearing in mind the modifications appeared once that costumes run over their communitary borders. On the other hand, some particular clothing patterns, can become a symbol of a given community, emerging then a stereotyped image of them coinciding with the regarded as the true version of the costume. In the case of Extremadura, and failing other cultural valid indicators, the female costume from Montehermoso (Cáceres) become, then, a regional symbol starting from the manipulation and distortion of its formal traditional materials for the acquisition of a specific and differential image, a process that can be regarded as the invention of a tradition. 